\title{
Co-ordinating co-ordination: The European Commission and the culture Open Method of Co-ordination
}

\begin{abstract}
This article examines the role of the European Commission in non-legislative policy co-ordination in the European Union. Using the Open Method of Co-ordination in the oft-neglected sector of cultural policy as a case study, it argues that rather than a neutral facilitator as it appears on paper, the Commission occupies both a political and administrative leadership role in the operation of the culture OMC. Through analysis of policy documentation, interview, and participant observation material, the article demonstrates how the Commission has operated as a key driver and agenda-setter in the field, exposing the inter-institutional dynamics in a competence in which the EU has a supporting role. The findings thus have broader implications for the study of agenda-setting and European integration in policy sectors where the EU holds a supporting competence.
\end{abstract}

Keywords: European Commission, policy co-ordination, Open Method of Co-ordination, cultural policy, informal institutions

\section{Introduction}

This article examines the role of the European Commission in policy co-ordination using a case study of the Open Method of Co-ordination (OMC) in the field of cultural policy. ${ }^{1}$ The Commission, an institution 'at the very heart of the EU system' (Nugent, 2010, p. 105), has been the subject of much academic attention (see, for example, Kassim et al., 2013 for a recent overview). However, most of this literature focuses on its role in the Community method; its functions and responsibilities in non-legislative policy co-ordination have not been studied as extensively. Given that issues of competence, subsidiarity, legitimacy, and democracy are key in a post-Maastricht EU, agenda-setting dynamics between the Commission and Member States in areas of supporting competence are particularly important to study, as these "new" modes of governance occupy 'an unsettled constitutional space'

\footnotetext{
${ }^{1}$ The European Union does not explicitly define cultural policy, but it is generally agreed to be policies associated with the arts and culture (including cultural institutions such as museums), communications and media (including, for example, broadcasting and publishing), citizenship and identity, and spatial culture (urban and cultural planning, and cultural heritage) (Craik, Davis, and Sunderland, 2000).
} 
(Armstrong, 2008, p. 416). ${ }^{2}$ The central question this article asks is therefore what role does the European Commission play in the operation of the Open Method of Co-ordination in the field of culture?

The OMC is a method of intergovernmental policy co-ordination that takes place primarily in policy areas where the EU has a supporting competence and where the subsidiarity principle is applied. While the literature on the OMC is extensive (see for example Borrás and Radaelli's 2010 literature review), few studies have focused explicitly on the role of the European Commission within the OMC. As such, there is scope to focus more closely on inter-institutional dynamics in the OMC's operation. Indeed, there is disagreement in the literature on whether non-legislative modes of governance such as the OMC empower the Commission or take away from it. Does the so-called "new intergovernmentalism" (Bickerton et al., 2015), whereby the European Council and Council of Ministers are in the driver's seat, apply in the case of policy co-ordination as well?

Agreeing with a wide body of literature on the Commission's role in the Community method, some have argued that policy co-ordination tools such as the OMC have meant a decreased role for the Commission overall (Nugent, 2010), as political priorities are set in the Council, restricting the Commission's role to one of an administrative nature. Others maintain that the Commission is able to drive the agenda. For example, Deganis (2006) has found that, in the case of the OMC in employment, the Commission has been a key driver of further integration. Souto-Otero et al.’s (2008, p.232) findings in the OMC in education and vocational training policy indicate that the Commission 'has been active in extending its

\footnotetext{
2 "New" modes of governance, including the $\mathrm{OMC}$, are characterized by their voluntary nature, reliance on multi-level networks, and civil society participation (see Héritier and Rhodes, 2010).
} 
competences' in the field. Meanwhile, in the field of social policy, several contributions have shown the key role that the Commission had played (see, for example, Cram, 1993; Hantrais, 2007; Anderson, 2015). Linda Hantrais, for example, concluded that the Commission 'exploited the ambiguities and lack of precision in the treaties to take forward non-binding legislation and soft law' in social policy (Hantrais, 2007, p.258). Similarly, Vollaard et al. (2016) found the Commission to be a driver of a European healthcare union. It is thus 'not obvious' that the OMC has weakened the Commission (Borrás and Jacobsson, 2004, p.198).

Cultural policy is another sector to add to this growing body of work on the inter-institutional dynamics of policy co-ordination. A cultural competence was first introduced in the Treaty on European Union in 1992, though the Community was involved in the sector before this (see Craufurd Smith, 2004; Sassatelli, 2009; and Shore, 2000). ${ }^{3}$ Culture is a supporting competence: Member States retain control over their own cultural policies and the EU's role is supplementary. The objective of the culture OMC is to provide a platform for Member States to share and exchange ideas based on commonly agreed policy priorities (Council of the European Union, 2007; Ecorys, 2013b). Cultural policy is an under-represented sector in EU policy studies, and one that Member States are 'particularly disinclined' (Littoz-Monnet, 2007 , p. 2) to transfer more powers in. It thus makes a good case study because of the controversy surrounding the degree and nature of the EU's participation in this field (Craufurd Smith, 2004; Littoz-Monnet, 2007).

The article first discusses the Commission within the EU political system, and then gives a brief overview of the EU's involvement in cultural policy. The bulk of the paper is dedicated

\footnotetext{
${ }^{3}$ The EU's powers with respect to culture are outlined in Article 167 in the Treaty of the Functioning of the European Union.
} 
to exploring the role of the Commission, framed around exposing the difference between what the Commission's role in the OMC appears on paper and what actually happens in practice. Ultimately it finds that it is the Commission that has been the driver of further cooperation in EU cultural policy co-ordination, and that while the Council of Ministers acts as a "check" on the Commission's power, the Commission is able to exert a great deal of influence over the entire process.

\section{The European Commission and policy co-ordination}

Most research on the role of the Commission in EU governance looks at its role within the Community method, whereby it can act as a policy entrepreneur. ${ }^{4}$ This body of literature has led to valuable insight into the way the Commission works, most notably with regards to its agenda-setting powers. However, there is still debate about the overall extent to which the Commission is able to "drive" the direction of the EU (Bickerton et al., 2015, p. 237). These issues concern the Commission's legitimacy given its status as an unelected body as well as the division between bureaucratization and politicization (Coombes, 1970; Hooghe, 2002; Moravscik, 2002; Nedergaard, 2007; Wille, 2013).

There is general agreement that the European Commission has become less powerful since the Maastricht Treaty, due to a combination of treaty changes, the aftermath of the Santer Commission's actions, popular pressure to democratize policymaking, and pressure from Member States to act unilaterally on matters of the second and third pillars (see Kassim et al., 2013, ch.5; Bickerton et al., 2015, introduction). However, this assertion is usually made in

\footnotetext{
${ }^{4}$ Wallace and Wallace (2007) identify five different policy-making modes in the EU, each which 'reveals differences in the roles and behaviour of the various key actors, in their variety of approaches to policy dilemmas, and in the diversity of instruments used' (p. 341).
} 
the context of policy sectors in which the EU has an exclusive or shared competence. What about supporting competences? In these, policy co-ordination is a key mode of governance. The OMC has been criticized for the potential to facilitate "competence creep" through 'soften[ing] up issues for some future EU grab for power, or because it seeks policy convergence but by means other than the constitutionalised legislative process' (Armstrong, 2008, p. 417). However, most of the OMC literature focuses on the outcomes and effectiveness of co-ordination, rather than how it operates. The Commission's role is usually only mentioned in passing, typically in regards to its role of target monitoring and reporting (see, for example, de la Porte, 2002 and Nedergaard, 2005). There is also some work that has looked at the Commission's co-ordination capacities more generally (see Jordan and Schout, 2006). More consideration thus needs to be given to the role of the Commission in policy coordination in order to more fully capture European integration and governance dynamics.

The 2001 White Paper on EU Governance stipulates that 'the Commission should be closely involved [in the OMC] and play a co-ordinating role' (European Commission, 2001, p.18). In most policy fields, the Commission 'presents proposals on the European guidelines, organises the exchange of best practices, proposes indicators and benchmarks, and provides support to the process of implementation, monitoring, and peer review' (de la Porte, 2002, p. 44). These roles appear administrative in nature on paper, but as I argue throughout this article, they are political in nature:

'[c]onceputalising the Commission as disinterested [sic] authority that simply overlooks coordinative initiatives taking place among Member States repudiates a substantial body of empirical work demonstrating how the Commission, since its inception, has continuously pushed to increase its powers within the EU and promoted a further integrationist agenda in line with its own interests' (Deganis, 2006, p. 22-3). 
Therefore, despite the intergovernmental nature of the $\mathrm{OMC}$, it is still important to probe into the nature of the Commission's role as the body responsible for facilitating and managing policy co-ordination in this sector.

\section{EU cultural policy co-ordination}

Culture is a competence that 'entered the arena of EU jurisdiction under complex and contradictory conditions' (Sarikakis, 2007, p. 14). The EU became involved in the field in the mid-1970s in order to emphasize a shared cultural heritage and sense of cultural identity to gain more popular support for European integration (Craufurd Smith, 2004; Mattocks, 2017). Aside from the polysemic and contested nature of the definition of culture, there is a large range of cultural policy traditions in individual Member States (Staiger, 2013). This pluralism means that the form and legitimacy of EU involvement in the field is not obvious (Staiger, 2013). There are debates between and among Member States that wish to extend the competence and those that do not (Barnett, 2001; Littoz-Monnet, 2007), and policy harmonization is explicitly prohibited.

The EU has three main responsibilities in the field: (1) to encourage and facilitate cooperation between Member States; (2) to promote the incorporation of culture into other areas of EU jurisdiction; and (3) to cooperate with Member States on cultural action (see European Commission, 2007, 2016). Culture is part of the Directorate-General for Education and Culture (DG-EAC). The DG oversees programs such as the European Capital of Culture, European Heritage Days, and European Union prizes for Literature, Architecture, and Music, and the EU-wide funding programme Creative Europe 2014-2020, among others (see Mattocks, 2017; Psychogiopoulou, 2015). 
In 2007, the EU launched the Agenda for Culture, which included the introduction of an OMC. This opened 'a new chapter of cooperation on culture policy at European level' (Ecorys, 2013b, p. 2). The OMC work is programmed through triennial Work Plans for Culture, which outline the EU's strategic priority themes for the period concerned. To date there have been three Work Plans: 2008-2010, 2011-2014, and 2015-2018. The Work Plans are developed with the overarching goals of the Agenda for Culture and Europe 2020 in mind and are agreed on by Member States in the Council of Ministers. The Plans contain policy "priority areas" and subthemes within each priority area. Those subthemes that fall into the Member State domain operate with an OMC. Crucially, unlike most other policy fields, the culture OMC does not feature peer review, benchmarking, reporting, or "naming and shaming" based on targets and progress. It is thus an example of cooperative, rather than convergent co-ordination, with an emphasis on learning and exchange (Biagi, 1998; Ecorys, 2013b).

Within the body of work on EU public policy, there has not been much scholarly attention paid to policy-making in the cultural field, likely because it is often seen as a rather inconsequential policy area and has a comparatively low budget and impact (Gray and Wingfield, 2011). However, studies that do exist show that the Commission has played a key role in the development of EU action in this field, particularly since Maastricht. The work of Annabelle Littoz-Monnet $(2007,2012)$, for example, shows how the DG took an active stance in advancing further cultural action by framing culture as a tool to foster economic growth and competitiveness. Similarly, Patel (2013) argues that the Commission has exhibited 'integration by interpellation,' a technique of governmentality, to further deepen integration by facilitating debates on "Europeanness," without actually defining the word. More recently, Littoz-Monnet (2015) has shown how successful DG-EAC has been at the 
“creativity frame," advancing the EU's cultural policy agenda by promoting the economic potential of the cultural and creative industries, a shift from earlier discourses of shared identity that the EU emphasized in the early days of the competence (Shore, 2000).

\section{Theoretical and methodological frameworks}

To investigate the Commission's role in cultural policy co-ordination, I adopt a sociological institutionalism theoretical framework and use a combination of research methods. This allows for a qualitative, in-depth approach that focuses on institutions, actors, and structure. In this perspective, actors are said to act according to the logic of appropriateness (March and Olsen, 2009). An extension of this concept is the logic of practices (Jenson and Mérand, 2010), which links appropriateness with social norms and organizational practices. Agents are conceptualized as 'conscious and reflexive actors embedded in a given (institutional and indeed social) context' (Ripoll Servent and Busby, 2013, p. 6); thus, the concept of embedded agency (Ripoll Servent and Busby, 2013) reflects actions based on fit and appropriateness within a particular organizational setting. These in turn become routines that are reproduced in organizations (March and Olsen, 1989). This takes into account the importance of socially constructed roles influencing preferences, more so than individuals' own preferences (From, 2002).

It is also important to address the importance of informal institutions, as the gaps between formal and informal rules and behaviour is a central part of the analysis below. Defined as 'socially shared rules, usually unwritten, that are created, communicated, and enforced outside of officially sanctioned channels' (Helmke and Levitsky, 2004, p. 727), informal institutions can 'shape even more strongly [than formal] political behaviour and outcomes' 
(Helmke and Levitsky, 2004, p. 725). ${ }^{5}$ The full spectrum of political activity and its complex interactions and negotiations cannot fully captured by looking at formal institutions only; indeed ignoring informal aspects 'risks missing much of what drives political behaviour and can hinder efforts to explain important political phenomena' (Helmke and Levitsky 2004, p. 726). This gap between formal organizational structure and day-to-day practices is indeed where much of the richness in studying institutions lies.

By their very nature, informal behaviour and procedures are elusive; it is 'an attempt at studying the invisible or at least the opaque' (Christiansen and Neuhold, 2012, p. 2). This presents methodological challenges in that the researcher must understand a political system intimately in order to identify what is formal, what is informal, and most importantly expand on the relationship between them. Three types of information gathering - document analysis, semi-structured interviews, and participant observation - were used to study three OMC groups within the 2011-2014 Work Plan for Culture. These groups were in Priority A, 'Cultural diversity, intercultural dialogue, and accessible and inclusive culture,' and worked on themes of access and diversity in public arts and cultural institutions (Council of the European Union, 2010). 30 semi-structured interviews were carried out among three different groups: EU officials in the Commission and Council of Ministers, Member State representatives who attended the OMC meetings as nationally-appointed experts, and invited external experts who gave presentations to the groups. I also observed a two-day meeting of one group.

\footnotetext{
${ }^{5}$ Formal institutions, meanwhile, are defined as 'rules and procedures that are created, communicated through channels widely accepted as official' (Helmke and Levitsky, 2004, p.727).
} 
After all information was gathered, a thematic analysis was carried out in three stages. I first identified broad themes that emerged from the transcripts and my notes from observation. In a second stage, I refined these themes more comprehensively based on associations between interviewees. I then looked for linkages across the themes, and began to identify illustrative examples in each theme. In a third phase, I began to further reflect on "before" fieldwork and "after" fieldwork reflections to determine how what I had found differed from what I had expected. Where applicable, I also corroborated findings with the 2013 evaluation on the OMC carried out by Ecorys on behalf of the Commission (Ecorys, 2013a, 2013b).

\section{Findings: the European Commission and the culture OMC}

The culture OMC was created by DG-EAC after being proposed by the Commission in the 2007 Agenda for Culture (European Commission, 2007). It was then endorsed by the Council in a November 2007 resolution (Council of the European Union, 2007). That the suggestion of an $\mathrm{OMC}$ and its drive into being came from the Commission is important and telling: though the Commission is constricted by subsidiarity, the body has an interest in furthering EU cultural cooperation within its remit, as evidenced by this comment from an official in DG-EAC:

We always try to push for more competence because [...] at EU level we think that it's a good way to go, $[\ldots]$ it's maybe not always so efficient to "go" only national at this stage, so we think that it's good to co-ordinate more and more together, which of course doesn't mean imposing anything, or deciding anything, just trying to co-ordinate maximum [sic] and harmonize what can be harmonized... (Corrine, personal communication, April 2014). ${ }^{6}$

\footnotetext{
${ }^{6}$ All names are pseudonyms in order to protect anonymity.
} 
Corrine's statement outlines a cautiously activist stance: 'push[ing] for more competence.' At the same time, the Commission is also wary of treading on Member States' toes, due to concerns about subsidiarity. While they might want to push an activist agenda, the Commission is constrained by the Council of Ministers, as Corrine explains further: ... there was some reluctance to establish an OMC in culture. Some Member States didn't want that. Now they are happy with it, but they are always very attentive to what we are doing and why, and any formulation that could give the impression that we're trying to take the lead or do something is immediately raised and erased. Because of the subsidiarity principle (Corrine, personal communication, April 2014).

The Commission's formal role in the culture OMC, as outlined in the 2011-2014 Work Plan for Culture, is to, provide logistical and secretarial support to the work of the groups. As far as possible, it will support the groups by other suitable means (including studies relevant to their field of work) (Council of the European Union, 2010, p. 9).

The key words in this description are logistical and secretarial. The emphasis in the Work Plan is a managerial, facilitative role. The word that is most used to describe the Commission's role in the culture OMC by Commission policy officers themselves is secretariat. One policy officer is assigned to each OMC group, and follows that group from beginning to end. That individual is responsible for co-ordinating with Member States on the appointment of experts, co-ordinating with the groups' chairs, organizing meetings, and distributing information to the group. One policy officer, Fatima, described her role as such: I hold the secretariat - all the basic administrative support, but also support in terms of contact. So my role is not only to disseminate information - the agenda, the minutes, all that but give the group specific information on certain topics, [...] reports, studies, and so on. I provide this to them. But the work is done by them (personal communication, May 2014). 
The DG is also responsible for monitoring progress on the Work Plan as a whole; it produces both midterm and final evaluation reports (see European Commission, 2014).

On paper, then, the Commission's role appears to be limited - to facilitating and managing the OMC. It is also presented in a rather de-politicized fashion, because (political) policy priorities are set by Member States in the Council. However, while the publically-available descriptions of the Commission's role gives some idea of what the DG is responsible for, it does not shed much light on how exactly the $\mathrm{OMC}$ works in practice. It is thus necessary to dig deeper into the day-to-day practices of facilitating policy co-ordination. Indeed, findings from my research point to a more developed role than the Commission's (limited) role description in the Work Plan suggests:

The word used is secretariat. I would suggest it's slightly more (Jette, Commission, personal communication, May 2014).

... the Commission - they're doing much more than it's written in the documents, where it says simply 'secretariat,' sending the emails, etc. They do a lot more (Viktoria, Member State expert, personal communication, October 2014).

These quotes, from both a manager in the Commission as well as a Member State expert (who was also a former permanent representative in the Council), illustrate that what happens in practice is in fact more extensive. There are two main roles to explore here. The first is the DG's overseeing and evaluation responsibilities, which affords it a "bird's eye view" of the entire $\mathrm{OMC}$ process that no other actor within the OMC enjoys. The second is its day-to-day role in administering, facilitating, and managing the OMC. Taken together, these practices 
exemplify the Commission as both a political and administrative leader in the culture OMC (Hix, 1998, p. 45-6). These roles are discussed in turn below.

\section{Overseeing and evaluation responsibilities}

The Commission has a unique overview of the entire OMC process that neither the Council nor the Member States enjoy. To explain, it is useful to draft a historical timeline, using the 2011-2014 Work Plan as an example. First of all, the Work Plan is agreed on in the Council of Ministers. The Council, representing the Member States, is (in theory) 'to be found at the top of the decision-making pyramid, setting the overall objectives to be achieved by the Union' (de la Porte, 2002, p. 44). However, while the formal final decision on the Work Plan takes place in the Council, in practice, the Commission was found to play a strong role in its drafting and creation:

I have to admit that a lot of the drafting work came from the Commission side, as a sort-of ghost writer. They drafted a lot, which was then amended by the presidency team, but not dramatically. It isn't supposed to be like that! Because it's a Council work plan, but in reality a lot of the preparation was done with intensive cooperation of the Commission [civil] servants (Darya, Member State representative, personal communication, April 2014).

At any one time, the DG has the most knowledge of progress on the Work Plan: it has a 'cross-cutting view' of the bargaining positions of other actors involved in the process (Kassim et al., 2013, p. 130). The Commission also has a keen sense of what will be accepted in the Council, since a Commission official is present at Council meetings (Corrine, Commission, personal communication, April 2014). It is therefore in a position to propose policy priorities and sub-priorities that it feels will be widely accepted.

Secondly, the Commission is also responsible for monitoring progress during the period of the Work Plan, as well as disseminating OMC groups' work to the Council and any other 
relevant bodies (various personal communications, April and May 2014). After each OMC group is finished, the Commission co-ordinates the dissemination of the best practice policy report to the Council's working committee on cultural affairs and other relevant EU-level stakeholders (other dissemination is undertaken in the Member States by the participating experts themselves). ${ }^{7}$ The chair of the OMC group presents the report to the working committee in the Council, and this is co-ordinated by the Commission policy officer in charge of that group (Corinne, Commission, personal communication, April 2014).

Finally, at the end of a Work Plan cycle, the DG evaluates progress in preparation for the next plan. Slightly ironically, the institution of rotating presidencies, designed to make the Council more geographically representative, equal, and fair in terms of agenda-setting, has meant that the Commission's role is increased:

[W]e really feel that we're holding all of that together as the Commission, because [Council] presidencies come and go. We have the overview of the Work Plan, and we feel a bit of an ownership (Jette, Commission, personal communication, May 2014).

Therefore, due to their roles overseeing and evaluating the culture $\mathrm{OMC}$, as well as a prominent role in drafting the Work Plan's policy priorities, the Commission is at the centre of the overall political co-ordination of the culture OMC.

\section{Day-to-day management}

The second point to develop with regards to the Commission's role is that the body is also responsible for the OMC's day-to-day management. These tasks include scheduling meetings, taking notes during meetings, co-ordinating the appointment of Member State

\footnotetext{
${ }^{7}$ Each OMC group produces a report composed of thematic best practice examples as well as some analysis.
} 
experts, and supplying additional information when necessary, as Jette, a Commission official, outlines:

... we also play a role in the management of the meetings in the sense that when they arrive, chairs are often quite new, often their first OMC meeting, so we explain what the OMC is, how it works, and [...] we try to guide the management of the meeting (personal communication, May 2014).

Expanding on that, Jette explained the unique 'European' perspective that the Commission's policy officers bring to the OMC groups:

... the people in charge of assisting the groups [...] have a deep knowledge of the policy. They also have a European overview - which Member States don't always have. [...] So we bring in this knowledge and we are able to advise the chairs (Jette, Commission, personal communication, May 2014)

Jette's comment is interesting for two reasons. The first is her assertion that the policy officers have a 'European overview.' This suggests that the Commission views itself as a body that is privileged because of its overseeing role; in other words, there is value to be added at a European level and the Commission is working for the 'greater good' of the Union. ${ }^{8}$ The Commission is in the best position to have an idea of how consensus can be achieved. Secondly, by advising and providing information (such as statistics, reports, and current research on various policy topics), the Commission is in effect acting as a gatekeeper, passing on the information as they see appropriate. No other member of the group has the resources to do so, putting the Commission in a position to influence the direction of the groups, as the experts often rely on this information a great deal.

\footnotetext{
${ }^{8}$ Results from Kassim et al.'s (2013) major survey of Commission staff finds support for this view of the Commission: 79 per cent surveyed felt that Member States should not have a grip on decision-making, and 79.8 per cent (40 per cent 'strongly') felt that the Commission's role should not just be managerial in nature.
} 
Interestingly, the role of the group's chair (an expert from a Member State elected by the group) was found to be crucial with regards to how much the Commission was involved: a strong chair with considerable organizational skill and capacity means that the Commission rarely has to intervene in the meetings; conversely, a weak one means that the Commission plays a stronger role in their operation. Wasil, one Member State expert, described his experience as such:

....at the last meeting [the Commission] took [...] a big role in steering us; I guess they saw that if they don't, it will be a report with no target group. They were kind of editors, which I guess was good. Some of us wanted to be stronger in some recommendations, and they said that that's not our role. There was a discussion within the group what [the Commission's] mandate was, what our mandate was. In the end it was clear to me that they weren't only facilitating but also had the final say (personal communication, October 2014).

Wasil's comments demonstrate just how much influence the Commission can have. In one group studied, the Commission officer even wrote most of the final report (typically, this is done or at least co-ordinated by the elected chair of the group). Interestingly, findings from other OMCs are similar; writing in the case of the employment OMC, Deganis (2006, p. 29) found that ' $[\mathrm{w}]$ hereas a strong Chair will direct Committee proceedings a weak Chair will inevitably allow the Commission to assert itself as a dominant actor within EMCO. 9

\footnotetext{
${ }^{9}$ Deganis also includes a quote from one of her interviewees, an official within DG-Employment, who said '...the role of the Commission is sometimes co-chair and sometimes more behind the scenes' (2006, p.35, note \#20). Though I only concentrated on three groups within the 2011-2014 Work Plan, I expect this finding to be the case regardless of the thematic content of other culture OMC groups, as all of the policy officers I spoke to had worked in other priority areas as well.
} 
Taken together, these informal practices show that the Commission's role is far more developed than what might be expected from simply analyzing documents. No other actor in the process has as much knowledge of or involvement in the OMC at any one time than the Commission. Findings therefore demonstrate that the Commission occupies both a political and administrative leadership role in the operation of the culture OMC:

\section{Insert Table 1 here}

\section{Discussion}

The findings above show that European Commission sits at the epicentre of cultural policy co-ordination in the EU. The Commission created the Open Method of Co-ordination in this field and is responsible for its day-to-day operation and overall management. While on paper it would appear that the Council of Ministers takes ownership of the OMC, in practice, the process is steered by the Commission. But what ramifications does this have?

First of all, the Commission is able to influence the process through its various roles in drafting of the content of the Work Plan, its overseeing responsibilities, and its daily management responsibilities. This central role is thus one that enables it to set terms of reference, socializing the OMC's actors 'to internalize its conception of issues and objectives' (de la Porte, 2002, p. 44). The OMC is not a neutral activity; as a tool of policy co-ordination, it 'privilege[s] certain actors and interests and exclude others; [...] [and] drive[s] forward a certain representative of problems' (Lascoumes and Le Gales, 2007, p. 9). There is thus a blurring of the administrative and the political. The Commission derives its 
legitimacy based on its apoliticism. However, in practice it is involved in political decisions (see table 1).

In a competence such as culture, this raises fundamental questions concerning subsidiarity. After all, '[1] egally speaking, it is not for the EU to take the lead or to control' in this sector (Sandell, 1996, p.271). The Commission's responsibilities regarding the provision of information also aids in 'shaping of cognitive frames, $[\ldots]$ one of the most powerful instruments of rule' (Piattoni, 2010, p. 98). The themes the groups work on 'represent a powerful learning instrument, insofar as they are expected to destabilise prior understandings of issues and thus lead to incremental changes via an ideational shift in framing policy problems' (de la Porte and Pochet, 2012, p. 340). This makes the Commission an influential actor in the culture OMC.

Secondly, we can also draw conclusions regarding agenda-setting and inter-institutional dynamics. As formal guardians of the treaty, the Commission's first responsibility is consideration for the principle of subsidiarity, which was repeated by many of the policy officers I spoke to. In the cultural field, this taken seriously due to the sensitivity of the competence. However, the Commission has pushed, perhaps tentatively at times, for further co-ordination in the field since the early 1990s (Littoz-Monnet, 2012). While the Commission's policy officers say that they are facilitating and adding value, it is apparent that they believe that more can be done in terms of EU cultural cooperation, and have advanced an agenda that aspires to this.

This naturally raises the question of the Council's role, which, has been typically acknowledged in the small body of literature on EU cultural policy to be more restrained and 
resistant to further cooperation (Gordon and Adams, 2007; Littoz-Monnet, 2012). Here, we need to distinguish between power and influence (Golub, 1996). Ultimately, the Council still has the "final say," and it has agreed to further cooperation in the form of the OMC, with the knowledge that policy harmonization is prohibited in the treaty. However, while the Council retains power regarding the priorities of policy co-ordination, the Commission's influence diminishes the role of the Member States, due to the amount of bargaining and compromise involved. Though it could be argued there is not much "at stake" in these discussions given the peripheral nature of the competence, the setting of these policy priorities is important given concerns about subsidiarity in this field. The Commission may even 'take risks in order to push a certain position' (Bache et al., 2015, p. 335), knowing that it has certain allies within the Council working party, or indeed in the cultural sector itself. The Council's way of working, operating as it does on the basis of consensus, has the effect of constraining viewpoints on either side, appealing to a middle ground, which means a loss of power for individual Member States (Beyers and Dierickx, 1998). The Commission is in a position to influence this process. ${ }^{10}$

This lends support to the view that 'the Commission [has] routinely produced rules and policies that the member government would not have adopted though intergovernmental bargaining' (Sandholtz and Stone Sweet, 2012, p. 22). While my findings do not indicate that the OMC has allowed the Commission to "bypass" the subsidiarity principle (Borrás and Jacobsson, 2004, p. 198), it has allowed the Commission to expand its influence in cultural policy. Setting aside debates about the effectiveness of the OMC (see for example Kröger, 2009; Lodge, 2007), the paradox here is that the "rubber-stamping" nature of the Council's

\footnotetext{
${ }^{10}$ This is because, as actors become socialized to European ways of doing things, there is a blurring of national and transnational interests (Beyers and Dierickx, 1998; see also Hooghe and Marks, 2001).
} 
role is in fundamental opposition to the initial reason that many Member States were in favour of the $\mathrm{OMC}$ - because it reduced the role of the Commission, eliminated the Parliament entirely, and put the Council of Ministers at the epicentre of policy co-ordination (Lodge, 2007). But this is not quite what has happened in the case of the culture OMC.

If it were not for the Commission, would a culture OMC exist? All evidence points to "no," as the impetus for implementing an OMC came from the Commission and policy co-ordination has been steered by them since (European Commission, 2007). Advancing an agenda that promotes deeper cultural integration is in fact a norm for the European Commission (Awesti, 2007; Bulmer, 1993). These findings appear to be at odds with the view that the European Commission of the twenty-first century is a 'citadel under siege' (Kassim et al., 2013). Certainly, this is the case in many areas of EU competence (Bickerton et al., 2015). However, as I have shown, it is also important to look at integration dynamics in policy sectors where the EU has a supporting competence and determine to what extent the Commission is in the driver's seat (Schmidt and Wonka, 2012). Results from this research indicate a prominent role for the Commission and, to some degree, a loss of power and influence of the Member States. This deepens our understanding of dynamics in this field but it also raises important questions about the extent to which this is also the case in other supporting competences, and what conclusions about legitimacy and politicization can be drawn from this collective knowledge.

\section{Conclusions}

This article set out to examine the role of the European Commission in cultural policy coordination. It objective was to expose the differences between formal and informal institutions in co-ordination, demonstrating the value of insider work that looks closely at 
what goes on "behind the scenes," and in doing so to scrutinize inter-institutional dynamics in a supporting competence where policy co-ordination is the primary policy-making mode. While the Commission has been the subject of a great degree of research, much of this has been on its role in the Community method. Similarly, within the study of the OMC itself, only rarely is the Commission's role an explicit focus; rather, the literature tends to concentrate on the impacts (or lack thereof) of the $\mathrm{OMC}$ at the national level. However, looking at the roles of EU institutions is crucial - even more so in the case of policy coordination where the policy areas in contention are those that the EU does not have full competence in. What are the politics of consensus (Deganis 2006)? And where does the drive for increased co-ordination come from at this level? As an under-researched policy field and one that has unique challenges in terms of its symbolism, cultural policy offers an interesting test case to explore these dynamics.

The OMC has 'too often been presented as a technical, quasi apolitical policy-making tool' (de la Porte and Pochet, 2003, n.p.). This paper has interrogated some of these "politics of consensus' and has demonstrated that the European Commission's role in the culture OMC is one that is more developed and stronger than what might be expected from formal EU documentation. Not only does the DG play a strong hand in drafting the policy priorities - a role that, on paper, appears exclusively in the domain of the Council - it also has input into the final policy reports, 'structures the framework in which different players are to interact, and contributes to the structuring of the discourse through the documents it prepares' (de la Porte, 2002, p. 44). The Commission ultimately 'enjoys a superior political presence and visibility' and also 'is in a better position than others to manage the content and the directions of the information flows within the group' (Borrás, 2007, n.p.). 
These findings cannot be extrapolated to broader comments on European integration due to the sector-specific nature of inquiry. However, they can lend support to existing positions (From, 2002) and have demonstrated that a deeper understanding European integration can be achieved by examining the day-to-day dynamics of policy-making and the relationship of institutions within the process (Cram, 1994). Although it is restricted by the principle of subsidiarity, when policy co-ordination action is taken, it is the Commission that takes the lead. Findings therefore demonstrate that the Commission's 'logic of practices' is in fact to take an activist stance, within its remit, and to advance further European policy co-ordination in this field. 


\section{SOURCES}

Anderson, K. (2015) Social Policy in the European Union (Basingstoke: Palgrave Macmillan).

Armstrong, K. (2008) 'JCMS symposium: EU governance after Lisbon'. Journal of Common Market Studies, Vol 46, No. 2, pp. 413-26.

Awesti, A. (2007) 'The European Union, New Institutionalism and Types of Multi-Level Governance'. Political Perspectives Vol. 1, No. 2, available at http://www.politicalperspectives.org.uk/2007/08/issue-2-european-integration-and-the-member-statenew-directions-in-research/.

Bache, I., Bulmer, S., George, S. and Parker, O. (2015) Politics in the European Union, 4th edition (Oxford: Oxford University Press).

Barnett, C. (2001) 'Culture, policy and subsidiarity in the European Union: From symbolic identity to the governmentalisation of culture'. Political Geography, Vol. 20, No. 4, pp. 405-426.

Beyers, J. and Dierickx, G. (1998) 'The working groups of the Council of the European Union: Supranational or intergovernmental negotiations?' Journal of Common Market Studies Vol. 36, No. 3, pp. 289-317.

Biagi, M. (1998) 'The Implementation of the Amsterdam Treaty with Regard to Employment: Coordination or Convergence?' International Journal of Comparative Labour Law and Industrial Relations Vol. 14, pp. 325-336.

Bickerton, C.J., Hodson, D., and Puetter, U. (2015) The New Intergovernmentalism: States and Supranational Actors in the Post-Maastricht Era (Oxford: Oxford University Press). 
Borrás, S. (2007) ‘The European Commission as Network Broker’. European Integration online Papers (EIoP) Vol. 11, No. 1. Available at https://eiop.or.at/eiop/pdf/2007-001.pdf.

Borrás, S. and Jacobsson, K. (2004) 'The open method of co-ordination and new governance patterns in the EU'. Journal of European Public Policy Vol. 11, No. 2, pp. 185-208.

Borrás, S. and Radaelli, C. (2010) 'Recalibrating the open method of co-ordination' (Stockholm: SIEPS, Swedish Institute of European Policy Studies).

Bulmer, S.J. (1993) 'The Governance of the European Union: a New Institutionalist Approach'. Journal of Public Policy Vol. 13, No. 4, pp. 351-380.

Christiansen, T. and Neuhold, C. (2012) 'Introduction.' In Christiansen, T. and Neuhold, C. (eds.) International Handbook on Informal Governance (Cheltenham: Edward Elgar).

Coombes, D. (1970) Politics and Bureaucracy in the European Community (London: George Allen \& Unwin).

Council of the European Union (2010) 'Work Plan for Culture 2011-2014', Council Document 2010/C 325/01, 2 December. Available at http://www.consilium.europa.eu/uedocs/cms_data/docs/pressdata/en/educ/117795.pdf (accessed 12 May 2016).

Council of the European Union (2007) Resolution of the Council on a European Agenda for Culture. Document 2007/C 287/01, 16 November. Available at http://eur-lex.europa.eu/legalcontent/EN/TXT/PDF/?uri=CELEX:32007G1129(01)\&from=EN (accessed 12 May 2016). 
Craik, J., Davis, G., and Sunderland, N. (2000) 'Cultural policy and national identity.” In Davis, G. and Keating, M. (eds.) The Future of Governance: Policy choices (St. Leonards, Australia: Allen \& Unwin), pp.177-202.

Cram, L. (1994) 'The European commission as a multi-organisation: Social policy and IT policy in the EU'. Journal of European Public Policy Vol. 1, No. 2, pp. 195-217.

Cram, L. (1993) 'Calling the tune without paying the piper? Social policy regulation: The role of the commission in European community social policy'. Policy and Politics Vol. 21, No. 2, pp. 135-146.

Craufurd Smith, Rachael (ed.) (2004) Culture and European Union Law (Oxford: Oxford University Press).

de la Porte, C. (2002) 'Is the open method of co-ordination appropriate for organising activities at European level in sensitive policy areas?' European Law Journal Vol. 8, No. 1, pp. 38-58.

de la Porte, C. and Pochet, P. (2012) 'Why and how (still) study the Open Method of Co-ordination (OMC)?' Journal of European Social Policy Vol. 22, No. 3, pp. 336-349.

de la Porte, C. and Pochet, P. (2003) The OMC intertwined with the debates on governance, democracy and social Europe. Research on the Open Method of Co-Ordination and European Integration prepared for Minister Frank Vandenbroucke, Minister for Social Affairs and Pensions, Belgium. Available at www.eucenter.wisc.edu/OMC/open12.html.

Deganis, I. (2006) 'The Politics Behind Consensus: Tracing the Role of the Commission Within the European Employment Strategy'. Journal of Contemporary European Research, Vol. 2, No. 1, pp. $21-40$. 
Ecorys (2013a) Evaluation of the open method of co-ordination and the structured dialogue, as the Agenda for culture's implementing tools at European Union level: final report for the European Commission Directorate-General for Culture and Education. Brussels: European Commission Directorate-General for Education and Culture.

Ecorys (2013b) Evaluation of the Agenda for Culture's implementing tools at EU level: annexes. Brussels: European Commission Directorate-General for Education and Culture.

European Commission (2016) Culture sector support. Available at:

http://ec.europa.eu/culture/policy/culture-policies/index en.htm (accessed 13 November 2016).

European Commission (2014) 'Report on the implementation and relevance of the Work Plan for Culture 2011-2014', COM(2014) 535 final, 25 August. Available at http://ec.europa.eu/transparency/regdoc/rep/1/2014/EN/1-2014-535-EN-F1-1.Pdf (accessed 12 May 2016).

European Commission (2007) 'Communication on a European agenda for culture in a globalizing world', COM(2007) 242 final, 10 May. Available at http://eurlex.europa.eu/LexUriServ/LexUriServ.do?uri=COM:2007:0242:FIN:EN:PDF (accessed 12 May 2016).

European Commission (2001) 'Communication from the Commission on European governance - A white paper', $\operatorname{COM(2001)} 428$ final, 12 October. Available at http://eur-lex.europa.eu/legalcontent/EN/TXT/HTML/?uri=URISERV:110109\&from=EN (accessed 12 May 2016).

From, J. (2002) 'Decision-making in a complex environment: a sociological institutional analysis of competition policy decision-making in the European Commission'. Journal of European Public Policy Vol. 9, No. 2, pp. 219-237. 
Golub, J. (1996) 'State Power and Institutional Influence in European Integration: Lessons from the Packaging Waste Directive'. Journal of Common Market Studies, Vol. 34, No. 3, pp. 313-339.

Gordon, C. and Adams, T. (2007) 'The European Union and Cultural Policy - Chimera, Camel or Chrysalis?' Consultative draft paper prepared for the European Cultural Foundation.

Gray, Clive and Wingfield, Melvin (2011) Are Governmental Culture Departments Important? An Empirical Investigation. International Journal of Cultural Policy. 17(5). pp. 590-604.

Hantrais, L. (2007) Social Policy in the European Union, $3^{\text {rd }}$ edn (Basingstoke, UK: Palgrave Macmillan).

Helmke, G. and Levitsky, S. (2004) 'Informal institutions and comparative politics: a research agenda'. Perspectives on Politics, Vol. 2, No. 4, pp. 725-740.

Héritier, A. and Rhodes, M. (2010) New Modes of Governance in Europe: Governing in the Shadow of Hierarchy (Basingstoke: Palgrave Macmillan).

Hooghe, L. (2002) The European Commission and the Integration of Europe: Images of Governance (Cambridge: Cambridge University Press).

Hooghe, L. and Marks, G. (2001) Multi-level governance and European integration (Lanham, USA: Rowman and Littlefield).

Jenson, J. and Mérand, F. (2010) ‘Sociology, Institutionalism and the European Union'. Comparative European Politics, Vol. 8, No. 1, pp. 74-92. 
Jordan, A. and Schout, A. (2006) The Co-ordination of the European Union: Exploring the Capacities of Networked Governance (Oxford: Oxford University Press).

Kassim, H. et al. (2013) The European Commission of the Twenty-First Century (Oxford: Oxford University Press).

Kröger, S. (2009) 'The Open Method of Coordination: Underconceptualisation, overdetermination, de-politicisation and beyond'. European Integration online Papers Vol. 13.

Littoz-Monnet, A. (2015) 'Encapsulating EU Cultural Policy into the EU’s Growth and Competiveness Agenda: Explaining the Success of a Paradigmatic Shift in Brussels.' In Psychogiopoulou, E. (ed.) Cultural governance and the European Union: Protecting and promoting cultural diversity in Europe (Basingstoke, UK: Palgrave Macmillan), pp. 25-36.

Littoz-Monnet, A. (2012) 'Agenda-setting Dynamics at EU Level: the case of the EU's Cultural Policy'. Journal of European Integration Vol. 34, No. 7, pp. 505-522.

Littoz-Monnet, A. (2007) The European Union and Culture: between Economic Regulation and Cultural Policy (Manchester: Manchester University Press).

Lodge, M. (2007) 'Comparing Non-Hierarchical Governance in Action: The Open Method of CoOrdination in Pensions and Information Society'. Journal of Common Market Studies Vol. 45, No. 2, pp. 343-365.

March, J.G. and Olsen, J.P. (2009) 'The Logic of Appropriateness.' ARENA, Centre for European Studies, University of Oslo. 
March, J.G. and Olsen, J.P. (1989) Rediscovering institutions: the organizational basis of politics (New York: The Free Press).

Mattocks, K. (2017) 'Uniting the citizens of Europe? Exploring the European Union's cultural policy agenda.' Forthcoming in O'Brien, D., Miller, T., and Durrer, V. (eds) Routledge Companion to Global Cultural Policy (London: Routledge).

Moravcsik, A. (2002) 'In defence of the democratic deficit: reassessing legitimacy in the European Union.' Journal of Common Market Studies. Vol 40, No. 4, pp.603-624.

Nedergaard, P. (2007) European Union Administration: Legitimacy and Efficiency (Leiden: Brill). Nedergaard, P. (2005) 'The Analysis of Mutual Learning Processes in the European Employment Strategy: A Social Constructivist Approach', working paper \#2005-004, Copenhagen: International Center for Business and Politics.

Nugent, N. (2010) The Government and Politics of the European Union, $7^{\text {th }}$ edn (Basingstoke: Palgrave Macmillan).

Patel, K.K. (2013) 'Integration by Interpellation: The European Capitals of Culture and the Role of Experts in EU Cultural Policies'. Journal of Common Market Studies Vol. 51, No. 3, pp. 538-554.

Piattoni, S. (2010) The Theory of Multi-level Governance: Conceptual, Empirical, and Normative Challenges (Oxford: Oxford University Press).

Psychogiopoulou, E. (ed) (2015) Cultural governance and the European Union: protecting and promoting cultural diversity in Europe (Basingstoke: Palgrave Macmillan). 
Ripoll Servent, A. and Busby, A. (2013) 'Introduction: Agency and influence inside the EU institutions'. In Ripoll Servent, A. and Busby, A. (eds.) Agency and influence inside the EU institutions, European Integration online Papers (EIoP) special issue, Vol. 17, pp. 1-22.

Sandell, T. (1996) ‘Cultural Issues, debate, and programmes'. In Barbour, P (ed.) The European Union Handbook (Chicago and London: Fitzroy Dearborn), pp. 268-278.

Sandholtz, W. and Stone Sweet, A. (2012) 'Neo-functionalism and supranational governance.' In Jones, E., Menon, A., and Weatherill, S. (eds) The Oxford Handbook of the European Union (Oxford: Oxford University Press), pp.18-33.

Sarikakis, K. (2007) 'The Place of Media and Cultural Policy in the EU.' In Sarikakis, K. (ed.) Media and cultural policy in the European Union (Amsterdam and New York: Rodopi).

Sassatelli, M. (2009) Becoming Europeans: Cultural Identity and Cultural Policies (Basingstoke: Palgrave Macmillan).

Schmidt, S.K. and Wonka, A. (2012) ‘European Commission.’ In Jones, E., Menon, A., and Weatherill, S. (eds) The Oxford Handbook of the European Union (Oxford: Oxford University Press), pp. 336-346.

Shore, C. (2000) Building Europe: The Cultural Politics of European Integration (London and New York: Routledge).

Souto-Otero, M., Fleckenstein, T., and Dacombe, R. (2008) 'Filling in the gaps: European governance, the open method of co-ordination and the European Commission'. Journal of Education Policy Vol. 23, No.3, pp. 231-249. 
Staiger, U. (2013) 'The European Capitals of Culture in context: cultural policy and the European integration process.' In Patel, K.K. (ed.) The Cultural Politics of Europe. European Capitals of Culture and European Union since the 1980s (London: Routledge), pp.19-38.

Vollaard, H., van de Bovenkamp, H., and Sindbjerg Martinsen, D. (2016) 'The making of a European healthcare union: a federalist perspective'. Journal of European Public Policy, Vol. 23, No. 2, pp. $157-176$.

Wallace, H. and Wallace, W. (2007) 'Overview: the European Union, Politics and Policy-making.' In Jørgensen, K.E., Pollack, M., and Rosamond, B. (eds.) The Handbook of European Union Politics (London: Sage), pp 339-358.

Wille, A. (2013) The Normalization of the European Commission: Politics and Bureaucracy in the EU Executive (Oxford: Oxford University Press). 


\section{List of interviews}

All names are pseudonyms.

\begin{tabular}{|c|c|c|c|}
\hline Alfred & 14 April 2014 & Council of Ministers official & In person, Brussels \\
\hline Beatrice & 14 April 2014 & Council of Ministers official & In person, Brussels \\
\hline Corinne & 15 April 2014 & European Commission official & In person, Brussels \\
\hline Darya & 22 April 2014 & Sub-national government representative & In person, Brussels \\
\hline Edward & 24 April 2014 & European Commission official & In person, Brussels \\
\hline Fatima & 20 May 2014 & European Commission official & In person, Brussels \\
\hline Georg & 22 May 2014 & Member State expert & In person, Brussels \\
\hline Hanna & 22 May 2014 & Member State expert & In person, Brussels \\
\hline Jette & 23 May 2014 & European Commission official & In person, Brussels \\
\hline Luise & 4 June 2014 & Member State expert & Telephone \\
\hline Markus & 16 June 2014 & Member State expert & Telephone \\
\hline Nils & 24 June 2014 & Member State expert & Telephone \\
\hline Oskar & 27 June 2014 & Member State expert & Telephone \\
\hline Paulina & 30 June 2014 & Member State expert & Telephone \\
\hline Quentin & 11 July 2014 & Member State expert & Telephone \\
\hline Ruth & 14 July 2014 & Member State expert & Telephone \\
\hline Salma & 28 July 2014 & Member State expert & Telephone \\
\hline Timo & 18 Sept. 2014 & Member State expert & Telephone \\
\hline Ulla & 6 Oct. 2014 & Member State expert & Telephone \\
\hline Viktoria & 13 Oct. 2014 & Member State expert & Telephone \\
\hline Wasil & 17 Oct. 2014 & Member State expert & Telephone \\
\hline Julita & 17 Oct. 2014 & Member State expert & Telephone \\
\hline Yvette & 5 Nov. 2014 & Invited guest expert & Telephone \\
\hline Zafar & 6 Nov. 2014 & Invited guest expert & Telephone \\
\hline Alain & 11 Nov. 2014 & Invited guest expert & Telephone \\
\hline Bartek & 14 Nov. 2014 & Invited guest expert & Telephone \\
\hline Camilla & 14 Nov. 2014 & Invited guest expert & Telephone \\
\hline Delores & 21 Nov. 2014 & Invited guest expert & Telephone \\
\hline Elin & $\begin{array}{l}\text { Oct./Nov. } \\
2014\end{array}$ & Invited guest expert & Email \\
\hline Frederick & 3 Dec. 2014 & Invited guest expert & Telephone \\
\hline
\end{tabular}


Table 1: Summary of DG-EAC's roles

\begin{tabular}{|c|c|}
\hline Political & Administrative \\
\hline $\begin{array}{l}\text { - Drafting the Work Plan; } \\
\text { - Monitoring progress of policy priorities } \\
\text { in the Work Plan; } \\
\text { - } \text { Aiding Member States in the } \\
\text { appointment of participating experts; } \\
\text { - Writing the report; * } \\
\text { - Evaluating progress of the Work Plan in } \\
\text { general; } \\
\text { - Disseminating groups' outputs to the } \\
\text { * Council's Cultural Affairs Committee. } \\
\text { the three OMC groups studied. }\end{array}$ & $\begin{array}{l}\text { - Organizing meetings; } \\
\text { - Taking notes at OMC meetings; } \\
\text { - Distributing minutes; } \\
\text { - Distributing material such as case study } \\
\text { information, studies, and other such } \\
\text { reports }\end{array}$ \\
\hline
\end{tabular}

